University of Nebraska - Lincoln

DigitalCommons@University of Nebraska - Lincoln

Papers in the Earth and Atmospheric Sciences

Earth and Atmospheric Sciences, Department

$5-1900$

\title{
GLACIAL GROOVES AND STRIAE IN SOUTHEASTERN NEBRASKA
}

Erwin Hinckley Barbour

University of Nebraska-Lincoln

Follow this and additional works at: https://digitalcommons.unl.edu/geosciencefacpub

Part of the Earth Sciences Commons

Barbour, Erwin Hinckley, "GLACIAL GROOVES AND STRIAE IN SOUTHEASTERN NEBRASKA" (1900).

Papers in the Earth and Atmospheric Sciences. 337.

https://digitalcommons.unl.edu/geosciencefacpub/337

This Article is brought to you for free and open access by the Earth and Atmospheric Sciences, Department of at DigitalCommons@University of Nebraska - Lincoln. It has been accepted for inclusion in Papers in the Earth and Atmospheric Sciences by an authorized administrator of DigitalCommons@University of Nebraska - Lincoln. 


\section{GLACIAL GROOVES AND STRIAE IN SOUTHEAST- ERN NEBRASKA ${ }^{I}$}

Nebraska is so close upon the western as well as the southern limit of the drift that evidences of glacial action which might be commonplace elsewhere are rare and interesting here. The mere fact that glacial grooves and striae have been found seems worthy therefore of mention. Glacial drift, readily recognizable as such, does not extend far west of the 97th meridian, and in but one place in the state, on the Dakota-Nebraska boundary, does it reach the 98th meridian. East of the 97th meridian it is distinct and unmistakable, and it may be offered as a safe statement that probably in no other state is the glacial drift so generally recognized as such by the mass of the people. This is due to the presence of numerous bright red and purple bowlders of Sioux quartzite. They are unmistakable, and it is generally known that they have been transported from the region of Sioux Falls in South Dakota, and scattered along the eastern border of Nebraska, and south into Kansas. Bowlders of Sioux quartzite twenty feet in diameter are to be found as far south as the Nebraska-Kansas line. A heavy mantel of drift, overlaid by a hundred feet or so of loess, so effectually conceals the rocks that exposures are rare, and striations and similar evidence of glacial action, which may be common enough in fact, are not seen. The first were found by the author in 1894 on a slab of Carboniferous limestone in the old Reed quarry one mile northeast of Weeping Water.

Though not found exactly in place it was unmistakably native rock. The ledge from which it came has just been found by Mr. E. G. Woodruff (Univ. Nebr. I900). It is a narrow ledge perhaps 300 feet long by five to six feet wide, leveled, smoothed, and striated throughout. The grooves and striae run south eleven degrees east. One groove, the most conspicuous

${ }^{x}$ Paper read before the Nebraska Academy of Science, December 2, I 899. 


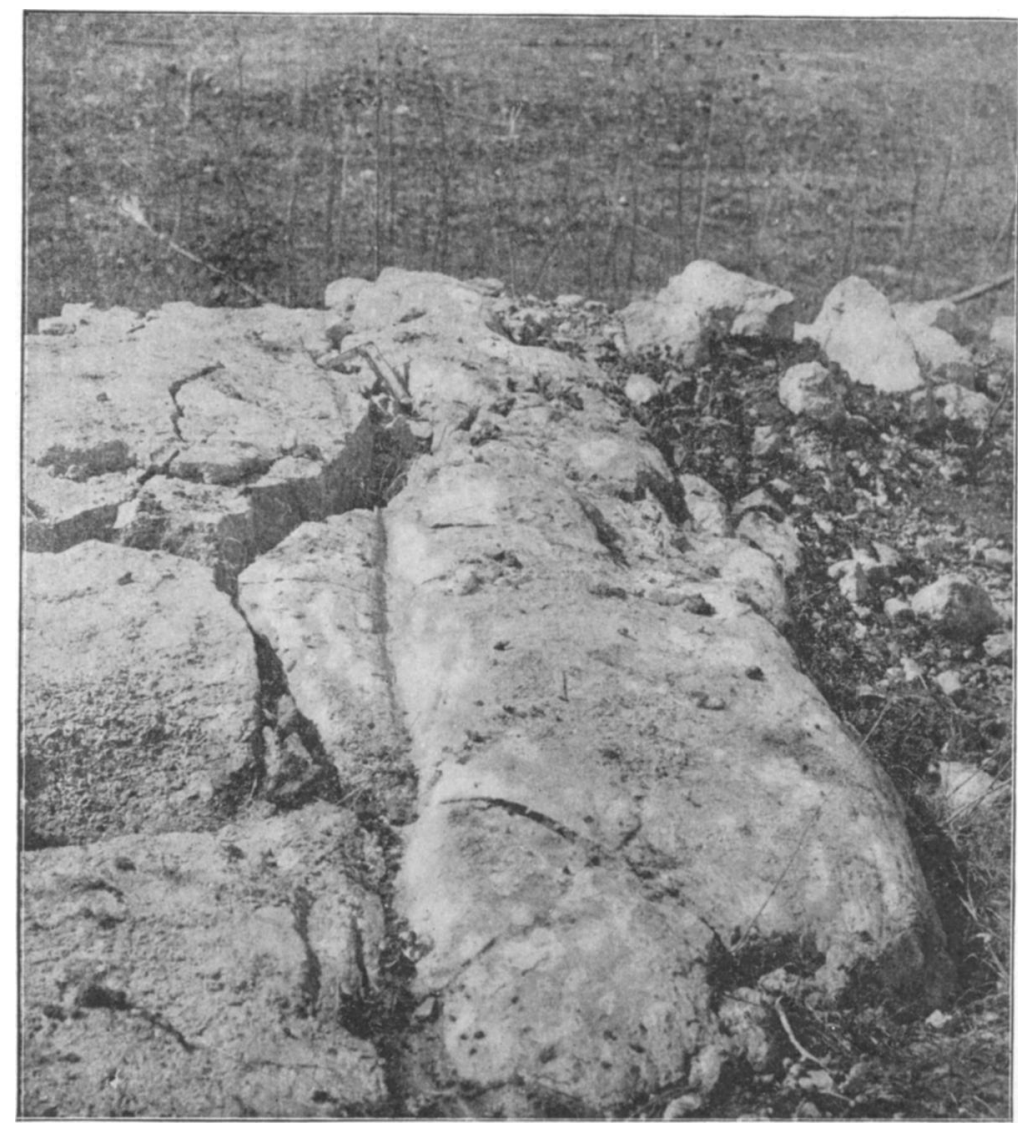

FIG. I.-Glaciated surface, carboniferous limestone, Weeping Water, Nebraska, badly shattered by a blast, yet plainly showing striae and grooves. The central groove varies from three to four inches in width, and is about one and one quarter inches deep, and runs south $29^{\circ}$ west. From a photograph by the writer.

noted, being three inches across and one and a quarter deep, ran south twenty-nine degrees west. There were numerous ragged grooves varying from one quarter to one half inch in depth, and innumerable closely crowded parallel striae. The whole surface was reduced to a plane, portions of which were well polished. Upon it rested a thin layer of drift consisting of a little clay, numerous large pebbles and an occasional bowlder of Sioux 


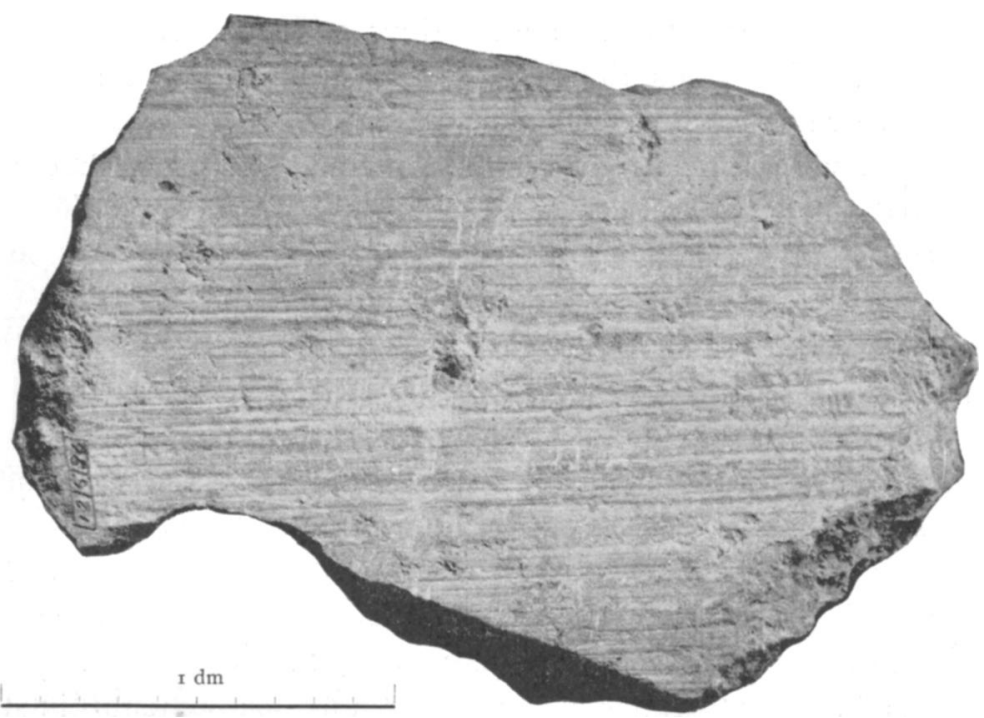

FIG. 2.-Cabinet specimen ( 7 by Io in.) in the State Museum of Nebraska, showing planed surface and glacial striae on carboniferous limestone, Weeping Water, Nebraska. Striae run south $\mathrm{II}^{\circ}$ east. Photograph of a specimen procured by the writer in 1894 .

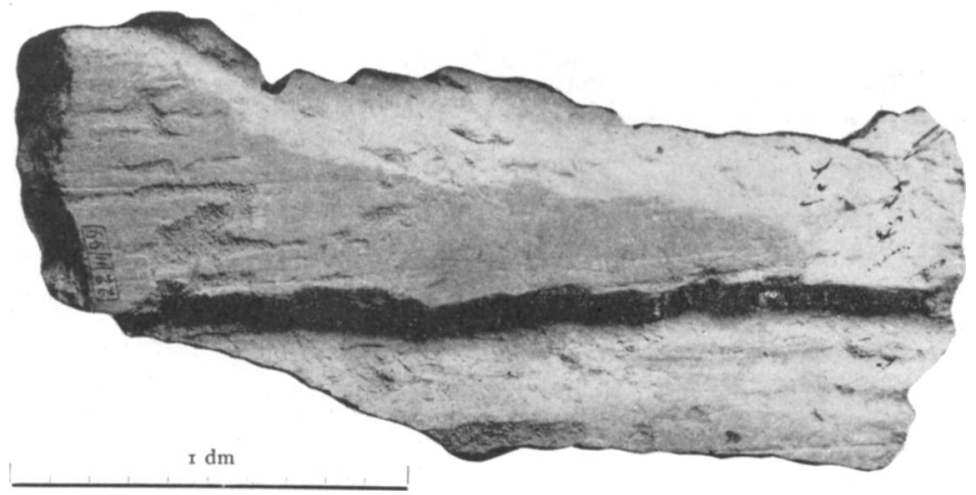

FIG. 3.-Cabinet specimen ( 7 by Io in.) in the State Museum of Nebraska, show ing planed and polished surface, striae, and a small glaciai groove, carboniferous limestone, Weeping Water, Nebraska. Photograph from a specimen secured by Mr. E. G. Woodruff, fall of 1899 . 
quartzite, the largest noted being about three feet through. The drift is thin here, nowhere exceeding a foot or two, as far as observed. Upon this thin but unmistakable layer of drift lies some twelve to fifteen feet of loess.

Two very tortuous miniature channels with polished and scored sides were noted. The curves were so abrupt that the striating and polishing must have resulted from the action of streams of glacial mud and gravel being under stress and driven with unusual force through the confined and winding channel.

This seems to be the point farthest south in the state where such grooves and striae have been noted. At La Platte light grooves and striae have been reported in the Carboniferous limestone. In the Dakota Cretaceous near South Bend, Mr. Charles N. Gould has observed parallel grooves which may be glacial, or as he thinks more likely artificial, being made by the Indians in former times when sharpening implements in the sandy rock of this formation. In the spring a considerable area at Weeping Water will be stripped of the overlying drift and loess, at which time it can be examined to much greater advantage than now.

Erwin Hinckley Barbour.

The UNIVERSity OF NeBraska. 